\title{
Development and Validation of a New Reverse Phase Liquid Chromatographic Method for the Assay of Tilorone
}

\section{Yenda Manishankar* and Mukthinuthalapati Mathrusri Annapurna}

Department of Pharmaceutical Analysis and Quality Assurance, GITAM Institute of Pharmacy, GITAM (Deemed to be University), Visakhapatnam, India

*Corresponding Author: Yenda Manishankar, Department of Pharmaceutical Analysis and Quality Assurance, GITAM Institute of Pharmacy, GITAM (Deemed to be University), Visakhapatnam, India.
Received: May 22, 2021

Published: July 21, 2021

(C) All rights are reserved by Yenda

Manishankar and Mukthinuthalapati

Mathrusri Annapurna.

\section{Abstract}

A new RP-HPLC method has been proposed for the assay of Tilorone in API and its tablet dosage forms. Tilorone is an anti-viral immune stimulating medication. It can be used for the treatment of viral hepatitis A, B, C, urogenital tract and respiratory infections. It stimulates the formation of $\alpha-, \beta-, \gamma$-interferons and produces interferon intestinal epithelial cells, neutrophils, T-lymphocytes and hepatocytes in the body. A mobile phase composition consisting of tetra butyl ammonium hydrogen sulphate and acetonitrile was chosen for the chromatographic study on isocratic mode. C8 Agilent column has been used for the chromatographic elution of Tilorone and the HPLC system was monitored at $264 \mathrm{~nm}$ with flow rate $0.5 \mathrm{~mL} / \mathrm{min}$. Tilorone has shown linearity over the concentration range $0.05-40 \mu \mathrm{g} / \mathrm{mL}$ and the regression equation was $\mathrm{y}=428331 \mathrm{x}+24602$ with correlation coefficient 0.9999 . The LOD and LOQ are found to be 0.0138 and $0.0429 \mu \mathrm{g} / \mathrm{mL}$ respectively. The method was validated as per ICH guidelines. The proposed RP-HPLC method was found to be precise, accurate, and robust for the quantification of Tilorone in pharmaceutical dosage forms.

Keywords: RP-HPLC; Tilorone; Acetonitrile; ICH Guidelines

\section{Introduction}

Tilorone (CAS 0027591-97-is an effective anti-viral agent against influenza viruses, herpesviruses, hepato viruses etc. Tilorone hydrochloride (Figure 1) is a synthetic orally active interferon inducer which has anti-cancer as well as anti-inflammatory activities. The antiviral action of Tilorone is associated with the inhibition of translation of virus-specific proteins followed by the suppression of virus replication. Tilorone is a fluoren-9-ones derivative and it is an alpha 7-nicotinic aceetyl choline receptor agonist. It has a molecular formula $\mathrm{C}_{24} \mathrm{H}_{34} \mathrm{Cl}_{2} \mathrm{~N}_{2} \mathrm{O}_{3}$. $2 \mathrm{HCl}$ and molecular weight 483.47. Very few analytical methods were so far developed in the literature HPLC/MS/MS methods were developed by Zhang., et al. [2] and Xianhua., et al. [3] for the simultaneous quantification of Tiloronoxim and Tilorone in human urine in presence of an internal standard, Metoprolol and also in human blood respectively. Tilorone is an active major metabolite of Tiloronoxim. One spectrophotometric [4] method and one RP-UFLC [5] method were reported in the literature for the assay of Tilorone in pharmaceutical dosage forms. At present the authors proposed a new reverse phase liquid chromatographic method (RP-HPLC) for the quantification of Tilorone in tablets and the method were validated as per ICH guidelines [6].

\section{Materials and Methods}

Instrumentation and Chemicals

Acetonitrile (HPLC grade) and tetra butyl ammonium hydrogen sulphate (TBHS) were procured from Merck (India). Shimadzu Model HPLC system with C8 Agilent column and photodiode array 
detector were used for the chromatographic analysis. Tilorone was supplied by HONOUR Labs Limited (Hyderabad, India) as gift sample. Tilorone is available with brand names AMIXIN and LAVOMAX (Label claim: $60 \mathrm{mg}$ ) as film coated tablets.

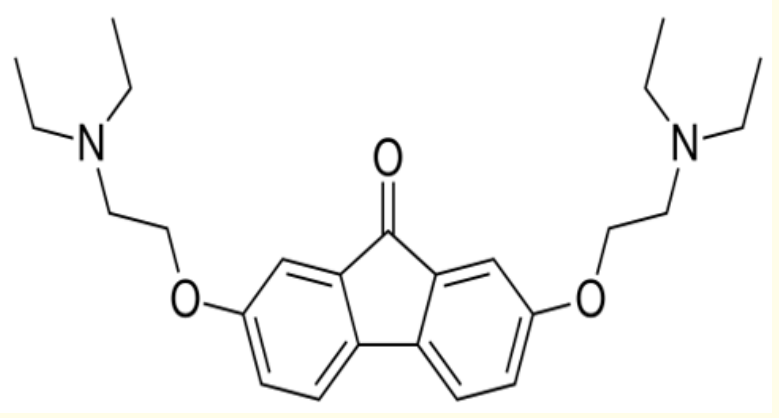

Figure 1: Chemical structure of Tilorone.

Preparation of tetra butyl ammonium hydrogen sulphate solution (pH 3.5)

The molecular weight of tetra butyl ammonium hydrogen sulphateis 339.5 grams/mole and it is an ion pairing reagent. $10 \mathrm{mM}$ solution of tetra butyl ammonium hydrogen sulphate was prepared by dissolving accurately 3.395 grams in HPLC grade water in a $1000 \mathrm{ml}$ volumetric flask and the solution was sonicated, filtered through a membrane filter and then used as mobile phase.

\section{Preparation of Tilorone stock (1000 $\mu \mathrm{g} / \mathrm{mL})$ solution}

$25 \mathrm{mg}$ of Tilorone was accurately weighed and dissolved in a 25 $\mathrm{mL}$ volumetric flask and made up to the volume with acetonitrile (HPLC grade) to obtain $1000 \mu \mathrm{g} / \mathrm{mL}$. This stock solution was diluted as per the requirement with the diluent and filtered through membrane filter before use. The diluent used was TBHS: Acetonitrile $(50: 50, \mathrm{v} / \mathrm{v})$.

\section{Method validation [6]}

Linearity study

A series of solutions $(0.05-40 \mu \mathrm{g} / \mathrm{mL})$ were prepared from the stock solution and diluted with mobile phase. $20 \mu \mathrm{L}$ of each of these solutions were injected in to the HPLC system and the peak area of each chromatogram was noted. A calibration curve was drawn by plotting the concentration on the $\mathrm{x}$-axis and the corresponding mean peak area values on the y-axis.

\section{Precision study}

Precision study was performed on the same day with three different concentrations and on different days using three different concentrations which are called as Intraday and Inter-day precision studies respectively. Three different concentrations 5, 10 and $20 \boldsymbol{\mu g} \mathbf{m L}$ of Tilorone solutions were prepared for intraday and interday precision studies and each solution was injected three times $(n=3)$ on the same day and on three consecutive days and the average peak area was calculated from the individual chromatograms obtained.

\section{Accuracy study}

The accuracy study was performed using the standard addition method. In this study the recovery values and the \% RSD values were calculated. In this method $50 \%, 100 \%$ and $150 \%$ of the pure drug (API) solutions were added to a fixed concentration of the extracted formulation solution and $20 \mu \mathrm{L}$ of each of these resultant solutions were injected $(n=3)$ in to the HPLC system and the peak area of each chromatogram was noted. The mean peak area was calculated and there by the percentage recovery was calculated using the linear regression equation obtained in the linearity study.

\section{Robustness study}

Robustness is one of the important validated parameters and in this study small changes such as flow rate $( \pm 0.1 \mathrm{~mL} / \mathrm{min})$, mobile phase ratio $( \pm 2 \%), \mathrm{pH}$ and detection wave length $(259 \mathrm{~nm}$ and $269 \mathrm{~nm}$ ) were incorporated in the optimized method and $20 \mu \mathrm{L}$ of $10 \mu \mathrm{g} / \mathrm{ml}$ of solution was injected $(\mathrm{n}=3)$ in to the HPLC system after attaining the base line with the incorporated changes one by one and the peak area of each chromatogram obtained was noted. The mean peak area of the chromatograms obtained from each incorporated change was calculated and there by the percentage recovery was also calculated using the linear regression equation obtained in the linearity study.

\section{Assay of commercial formulation (Tablets)}

20 tablets of two different brands of Tilorone available in pharmacy store were purchased, weighed powdered. Powder equivalent to $25 \mathrm{mg}$ Tilorone was weighed accurately and extracted with HPLC grade acetonitrile. The extracted solution was further diluted with the mobile phase, sonicated for half an hour and filtered through $0.45 \mathrm{~mm}$ membrane filter before injecting in to the HPLC system to prevent the particulate matter if any. $20 \mu \mathrm{L}$ of these solutions were injected $(n=3)$ in to the HPLC system and the mean peak area was noted from the respective chromatograms. The percentage of purity was calculated by substituting the mean peak area value in the linear regression equation.

\section{Results and Discussion}

A new reverse phase liquid chromatographic method has been developed for the determination of Tilorone in pharmaceutical 
dosage forms using Shimadzu Model HPLC system with C8 Agilent column and photo diode array detector. The previously published analytical methods were compared with the present proposed method in table 1. Mobile phase mixture consisting of tetra butyl ammonium hydrogen sulphate and acetonitrile was selected for the chromatographic study. Tetra butyl ammonium hydrogen sulphate is an ion pairing reagent. The run time was 10 minutes and the detection wavelength was at $264 \mathrm{~nm}$. The chromatographic study was performed isocratic mode with a flow rate of $0.5 \mathrm{~mL} / \mathrm{min}$.

\begin{tabular}{|c|c|c|c|c|}
\hline Method & $\begin{array}{c}\text { Mobile phase } \\
(\% \mathrm{v} / \mathrm{v})\end{array}$ & $\begin{array}{l}\text { Linearity } \\
(\mu \mathrm{g} / \mathrm{mL})\end{array}$ & Comments & Ref \\
\hline $\begin{array}{l}\text { HPLC-MS/MS } \\
\text { Metoprolol } \\
\text { (Internal standard) }\end{array}$ & $\begin{array}{c}\text { Methanol: } 15 \text { mMAmmonium bicarbonate } \\
\text { (pH 10.5) }\end{array}$ & $0.001-0.1$ & $\begin{array}{l}\text { Human urine } \\
\text { Gradient mode }\end{array}$ & {$[2]$} \\
\hline HPLC-MS/MS & $\begin{array}{c}\text { Methanol: } 15 \text { mMAmmonium bicarbonate } \\
\text { (pH 10.5) }\end{array}$ & $0.001-0.1$ & $\begin{array}{l}\text { Human Blood } \\
\text { Gradient mode }\end{array}$ & [3] \\
\hline Spectrophotometry & $\begin{array}{l}\text { Sodium acetate buffer (pH 4) Borate buffer } \\
\qquad(\mathrm{pH} 9.0) \\
\text { Phosphate buffer (pH 2.0) Phosphate buf- } \\
\text { fer (pH 5.0) }\end{array}$ & $0.4-14$ & Good linearity & [4] \\
\hline RP-UFLC & $\begin{array}{c}0.1 \% \text { TEA: Acetonitrile } \\
(\mathrm{pH} 3.2 \text { adjusted with OPA }) /(40: 60)\end{array}$ & $0.1-20$ & $\begin{array}{l}\text { Stability indicating } \\
\text { (PDA) }\end{array}$ & [5] \\
\hline RP-HPLC & $\begin{array}{c}\text { Tetra butyl ammonium hydrogen sulphate: } \\
\text { Acetonitrile (61:39) }\end{array}$ & $0.05-40$ & Ion pairing agent & $\begin{array}{l}\text { Present } \\
\text { method }\end{array}$ \\
\hline
\end{tabular}

Table 1: Comparison of previously published methods with the present method.

\section{Method development and optimization}

Initially a mobile phase consisting of tetra butyl ammonium hydrogen sulphate and methanol (20: 80) was chosen with flow rate $1.0 \mathrm{ml} / \mathrm{min}$ for the chromatographic study and Tilorone was eluted at 1.307 mins. Therefore methanol in the mobile phase was replaced with acetonitrile and the ratio was maintained at 50: 50 with flow rate $0.8 \mathrm{ml} / \mathrm{min}$. Tilorone was eluted at $1.466 \mathrm{~min}$ with theoretical plates less than 2000. Later the flow rate was decreased to $0.5 \mathrm{ml} / \mathrm{min}$ and the retention time of Tilorone was shifted to 1.917 min with theoretical plates more than 2000. To shift the retention time the organic phase was decreased and finally Tilorone was eluted at 2.338 mins and the system suitability parameters were satisfied. The method was optimised with mobile phase, TBHS: Acetonitrile $(61: 39, \mathrm{v} / \mathrm{v})$ with flow rate $0.5 \mathrm{ml} / \mathrm{min}$ and the detection was carried out at $264 \mathrm{~nm}$. The trials runs obtained during the optimization process were shown in Figure 2 and the summary of details was given in table 2 .

\begin{tabular}{|l|c|c|c|c|c|c|}
\hline Trial & Mobile phase (v/v) & Flow rate (mL/min) & Rt (min) & Theoretical plates & Tailing factor & Comment \\
\hline 1 & $\begin{array}{c}\text { TBHS: Methanol } \\
(20: 80)\end{array}$ & 1.0 & 1.307 & 1631.166 & 3.424 & $\begin{array}{c}\text { Tailing factor }>2 \\
\text { Theoretical plates }<2000 \\
\text { Rt less than } 2 \text { min }\end{array}$ \\
\hline 2 & $\begin{array}{c}\text { TBHS: Acetonitrile } \\
\text { (50:50) }\end{array}$ & 0.8 & 1.466 & 1934.812 & 1.639 & $\begin{array}{c}\text { Theoretical plates }<2000 \\
\text { Rt less than } 2 \text { min }\end{array}$ \\
\hline 3 & $\begin{array}{c}\text { TBHS: Acetonitrile } \\
\text { (50:50) }\end{array}$ & 0.5 & 1.917 & 2277.787 & 1.591 & Rt less than 2 min \\
\hline 4 & $\begin{array}{c}\text { TBHS: Acetonitrile } \\
\text { (61:39) }\end{array}$ & 0.5 & 2.338 & 2320.445 & 1.212 & Method optimized \\
\hline
\end{tabular}

Table 2: Method optimization. 

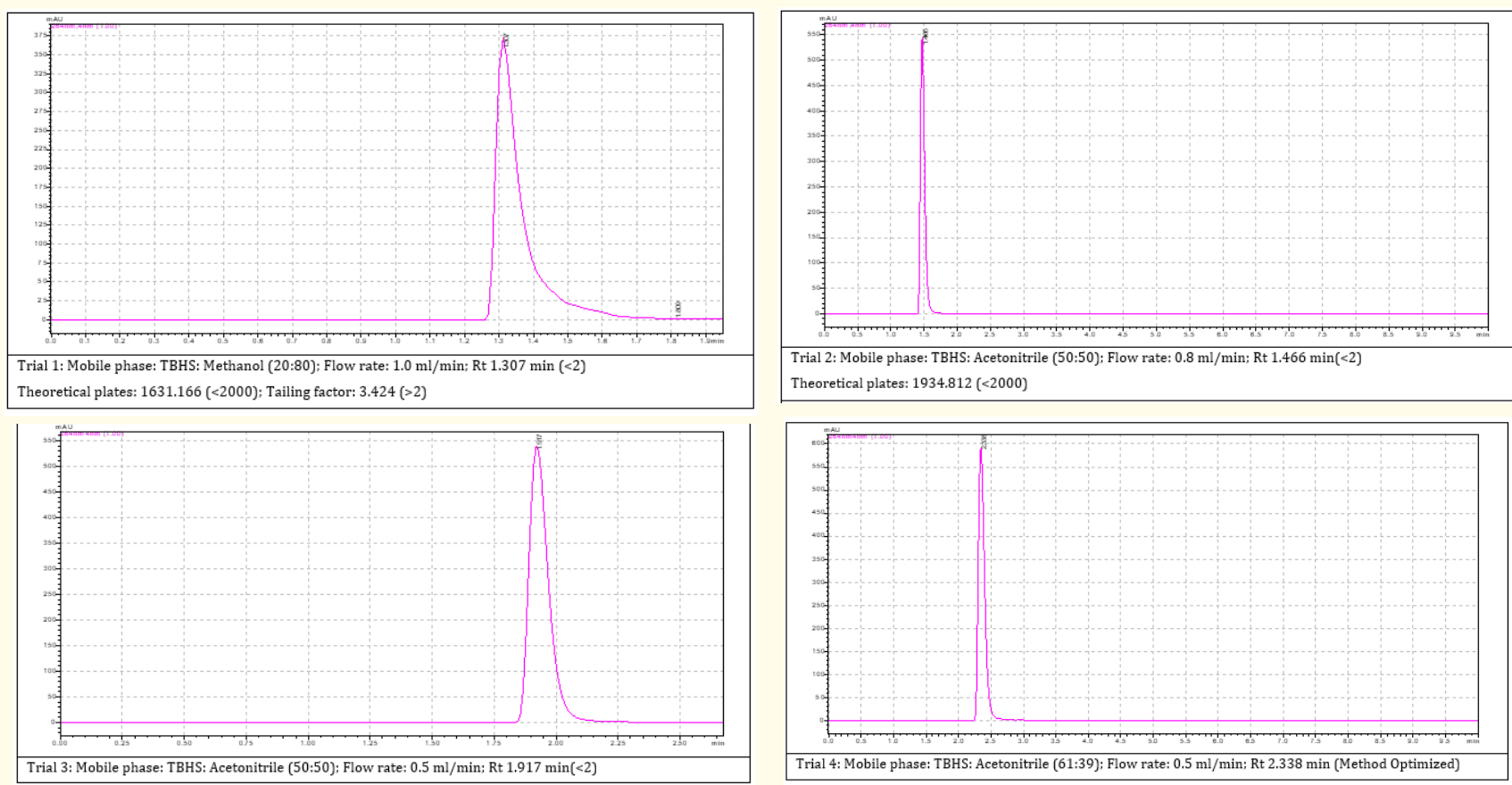

Figure 2: Chromatograms obtained during the method optimization of Tilorone $(10 \mu \mathrm{g} / \mathrm{ml})$.

\section{Method validation}

The proposed method was validated by linearity, precision, accuracy, robustness as per the ICH guidelines for the determination of Tilorone. Tilorone has shown linearity over the concentration range $0.05-40 \mu \mathrm{g} / \mathrm{mL}$ (Table 3 ) and the regression equation was $\mathrm{y}=$ $428331 x+24602$ with correlation coefficient 0.9999 . The LOD and
LOQ are found to be 0.0138 and $0.0429 \mu \mathrm{g} / \mathrm{mL}$ respectively. The calibration curve was shown in figure 3 . The representative chromatograms obtained for the placebo and that of Tilorone standard (API) were shown in Figure 4. The system suitability parameters are within the acceptable criteria.

\begin{tabular}{|l|c|c|c|c|}
\hline Conc. $(\boldsymbol{\mu g} / \mathbf{m L})$ & *Mean peak area & \%RSD & Theoretical plates & Tailing factor \\
\hline 0.05 & 24337 & 0.39 & 2498.226 & 0.979 \\
\hline 0.1 & 47923 & 0.23 & 2564.332 & 0.867 \\
\hline 0.5 & 232921 & 0.48 & 2778.329 & 1.221 \\
\hline 1 & 454256 & 0.32 & 2337.005 & 1.463 \\
\hline 2 & 873387 & 0.41 & 2464.754 & 1.301 \\
\hline 5 & 2231224 & 0.29 & 2332.290 & 1.495 \\
\hline 10 & 4403233 & 0.34 & 2302.556 & 1.374 \\
\hline 20 & 8455549 & 0.31 & 2569.534 & 1.290 \\
\hline 30 & 12943257 & 0.49 & 2645.189 & 1.392 \\
\hline 40 & 17142681 & 0.52 & 2561.267 & 1.269 \\
\hline
\end{tabular}

Table 3: Linearity study.

*Mean of three replicates. 


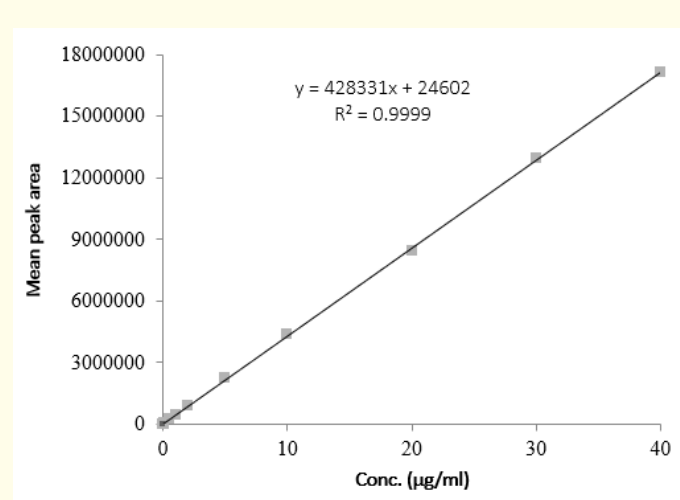

Figure 3: Calibration curve of Tilorone.

Intraday and inter-day precision were studied and the \% RSD was found to be $0.21-0.33$ and $0.38-0.59$ respectively $(<2.0 \%)$ showing that the method is precise (Table 4 and Table 5). The $\%$ RSD in accuracy was found to be 0.73-0.91 (<2.0\%) with a recov- ery of 99.33-99.47\%showing that the method is accurate (Table 6). In robustness study the $\%$ RSD was found to be $0.27-1.23$ which is less than 2.0 indicating that the method is robust (Table 7).

\begin{tabular}{|l|c|c|}
\hline \multirow{2}{*}{$\begin{array}{l}\text { Conc. } \\
(\boldsymbol{\mu g} / \mathbf{m L})\end{array}$} & $\begin{array}{c}\text { Peak area } \\
\text { (AUC) }\end{array}$ & *Mean peak area + SD (\% RSD) \\
\cline { 1 - 2 } 5 & 2231321 & $2231306 \pm 7363.31(0.33)$ \\
\hline 5 & 2231296 & \\
\hline 5 & 2231301 & \\
\hline 10 & 4423215 & \multirow{2}{*}{$4424190 \pm 9290.80(0.21)$} \\
\hline 10 & 4424136 & \\
\hline 10 & 4425219 & \\
\hline 20 & 8456024 & \multicolumn{1}{|c}{} \\
\hline 20 & 8455933 & \multirow{2}{*}{$8455876.67 \pm 2830.87(0.27)$} \\
\hline 20 & 8455673 & \multicolumn{1}{|c|}{} \\
\hline
\end{tabular}

Table 4: Intraday precision study.

*Mean of three replicates.

\begin{tabular}{|l|c|c|c|c|}
\hline \multirow{2}{*}{$\begin{array}{l}\text { Conc. } \\
(\boldsymbol{\mu g} / \mathbf{m L})\end{array}$} & \multicolumn{3}{|c|}{ *Mean peak area } & \multirow{2}{*}{$*$ *Mean \pm SD(\% RSD) } \\
\cline { 2 - 4 } & Day 1 & Day 2 & Day 3 & \\
\hline 5 & 2302562 & 2283012 & 2292261 & $2292611.67 \pm 9628.97(0.42)$ \\
\hline 10 & 4510022 & 4511214 & 4510354 & $4510530 \pm 26612.13(0.59)$ \\
\hline 20 & 8362533 & 8359847 & 8358475 & $8360285 \pm 31769.08(0.38)$ \\
\hline
\end{tabular}

Table 5: Interday precision study.

*Mean of three replicates.

\begin{tabular}{|c|c|c|c|c|}
\hline \multicolumn{3}{|l|}{ Conc $(\mu \mathrm{g} / \mathrm{mL})$} & \multirow{2}{*}{$\begin{array}{c}\text { *Average conc. } \\
\text { (\% RSD) }\end{array}$} & \multirow[b]{2}{*}{ \% Recovery } \\
\hline Formulation & $\begin{array}{l}\text { Pure } \\
\text { drug }\end{array}$ & Total & & \\
\hline 6 & 3 & 9 & \multirow[t]{3}{*}{$8.94(0.89)$} & \multirow[t]{3}{*}{99.33} \\
\hline 6 & 3 & 9 & & \\
\hline 6 & 3 & 9 & & \\
\hline 6 & 6 & 12 & \multirow[t]{3}{*}{$11.93(0.73)$} & \multirow[t]{3}{*}{99.41} \\
\hline 6 & 6 & 12 & & \\
\hline 6 & 6 & 12 & & \\
\hline 6 & 9 & 15 & \multirow[t]{3}{*}{$14.92(0.91)$} & \multirow[t]{3}{*}{99.47} \\
\hline 6 & 9 & 15 & & \\
\hline 6 & 9 & 15 & & \\
\hline
\end{tabular}

\begin{tabular}{|c|c|c|}
\hline Parameter & Condition & $\begin{array}{c}\text { *Mean peak area } \pm \text { SD } \\
(\% \mathrm{RSD})\end{array}$ \\
\hline \multirow{3}{*}{$\begin{array}{l}\text { Flow rate }( \pm 0.1 \\
\mathrm{ml} / \mathrm{min})\end{array}$} & 0.4 & \multirow{3}{*}{$4415984 \pm 44601.44$} \\
\hline & 0.5 & \\
\hline & 0.6 & \\
\hline \multirow{3}{*}{$\begin{array}{l}\text { Detection wave- } \\
\text { length }( \pm 2 \mathrm{~nm})\end{array}$} & 259 & \multirow{3}{*}{$4404521 \pm 11892.21(0.27)$} \\
\hline & 264 & \\
\hline & 269 & \\
\hline \multirow{2}{*}{$\begin{array}{l}\text { Mobile phase com- } \\
\text { position }\end{array}$} & 56: 44 & \multirow{3}{*}{$4405269 \pm 25991.09(0.59)$} \\
\hline & 61:39 & \\
\hline $\begin{array}{l}\text { TBHS: Acetonitrile } \\
( \pm 2 \%, v / v)\end{array}$ & $66: 34$ & \\
\hline \multirow{3}{*}{$\mathrm{pH}( \pm 0.1$ unit $)$} & 3.4 & \multirow{3}{*}{$4410256 \pm 54246.15$} \\
\hline & 3.5 & \\
\hline & 3.6 & \\
\hline
\end{tabular}

Table 6: Accuracy study.

*Mean of three replicates.

Table 7: Robustness study. 


\section{Assay of tilorone tablets}

The analytical method i.e. RP-HPLC method developed for the determination of Tilorone was validated and it was applied for the assay of marketed formulations. The percentage of recovery was found to be 99.82-99.88 (Table 8). The typical chromatogram obtained for the marketed formulations were shown in figure 4.

\begin{tabular}{|l|c|c|c|}
\hline Formulation & $\begin{array}{c}\text { Label } \\
\text { claim (mg) }\end{array}$ & $\begin{array}{c}\text { *Amount found } \\
\text { (mg) }\end{array}$ & $\begin{array}{c}\text { *Recovery } \\
\text { (\%) }\end{array}$ \\
\hline Brand I & 60 & 59.93 & 99.88 \\
\hline Brand II & 60 & 59.89 & 99.82 \\
\hline
\end{tabular}

Table 8: Assay of Tilorone.

*Mean of three replicates.
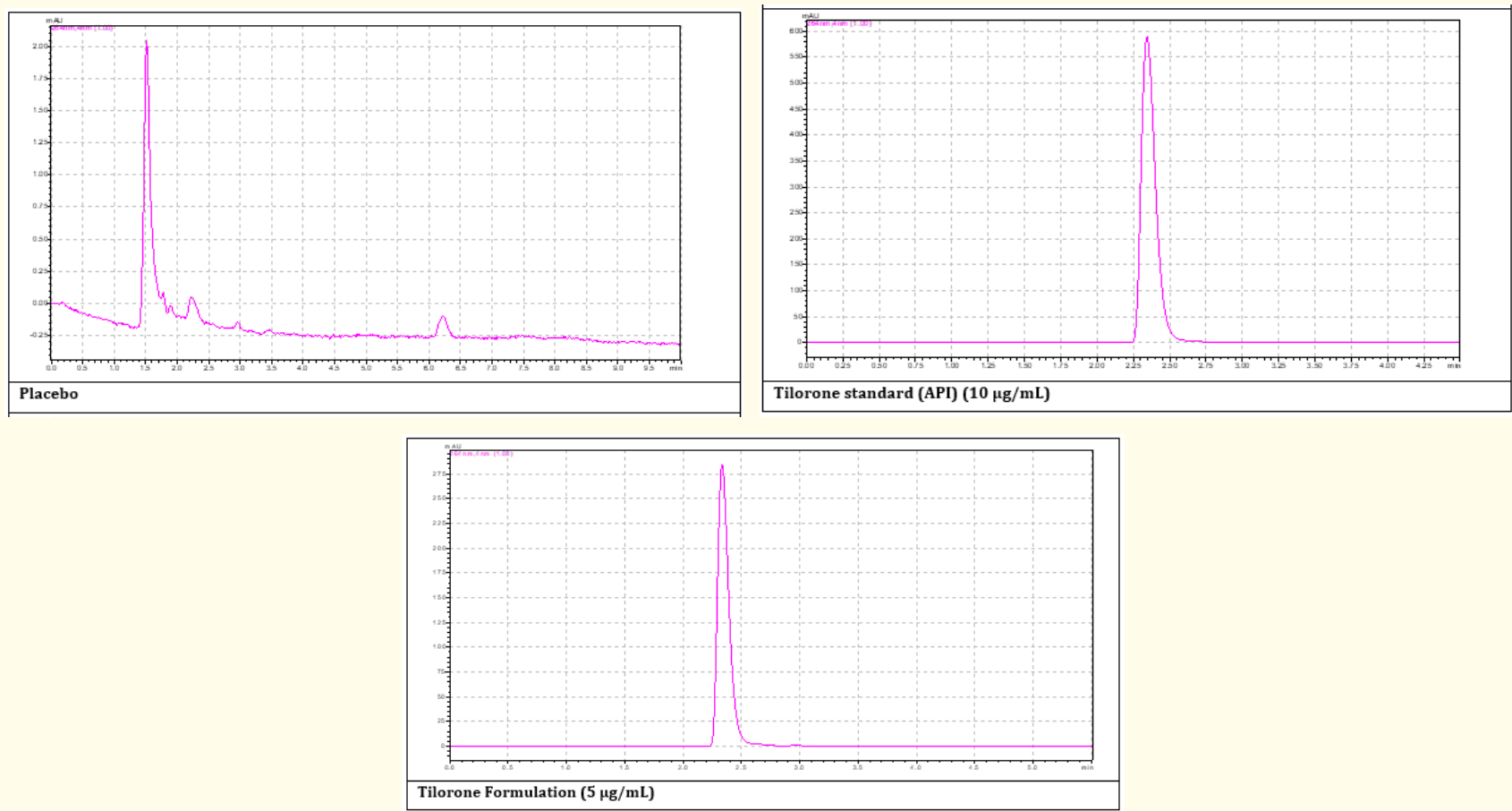

Figure 4: Representative chromatograms of Tilorone.

\section{Conclusion}

The proposed RP-HPLC method was validated as per ICH guidelines and can be used for the determination of Tilorone in pharmaceutical dosage forms. This method is also useful for performing the pharmacokinetic studies and also for the assay of Tilorone in biological samples.

\section{Acknowledgement}

The authors are grateful to HONOUR Labs Limited (Hyderabad, India) for supplying Tilorone as gift sample. There is no conflict of interest.

\section{Bibliography}

1. Stringfellow D and Glasgow L. "Tilorone hydrochloride: An oral interferon-inducing agent". Antimicrobial Agents Chemotherapy 2.2 (1972): 73-78.

2. Zhang X., et al. "Simultaneous quantification of Tiloronoxim and Tilorone in human urine by liquid chromatography-tandem mass spectrometry". Journal of Chromatography $B 875.2$ (2008): 349-357.

3. Xianhua Zhanga., et al. "Performance of Tiloronoxim and Tilorone determination in human blood by HPLC-MS/MS: Method validation, uncertainty assessment and its application to a pharmacokinetic study". Journal of Chromatography B 878. 3-4 (2010): 492-496. 
4. Mathrusri Annapurna M and Sri Valli D. "Derivative spectrophotometric methods for the determination of Tilorone - An Anti-retroviral Drug". Asian Journal of Pharmaceutics 12.1 (2018): S 288-S 295.

5. Hima Bindu G., et al. "New stability indicating ultrafast liquid chromatographic method for the determination of Tilorone in tablets". Research Journal of Pharmacy and Technology 11.9 (2018): 3950-3956.

6. ICH validation of analytical procedures: text and methodology Q2 (R1), International Conference on Harmonization (2005).

Volume 5 Issue 8 August 2021

(c) All rights are reserved by Yenda Manishankar and Mukthinuthalapati Mathrusri Annapurna. 